\title{
A series of civilian fatalities during the war in Syria
}

\author{
Adnan Çelikel, M.D., ${ }^{1}$ Bekir Karaarslan, M.D., ${ }^{2}$ Dua Sümeyra Demirkıran, M.D., ${ }^{1}$ \\ Cem Zeren, M.D., ${ }^{1}$ Muhammet Mustafa Arslan, M.D. ${ }^{1}$
}

${ }^{1}$ Department of Forensic Medicine, Mustafa Kemal University Faculty of Medicine, Hatay;

${ }^{2}$ Department of Forensic Medicine, Gaziantep University Faculty of Medicine, Gaziantep

\begin{abstract}
BACKGROUND: A considerable number of deaths due to firearm injuries have occurred during wars all over the world. In this study, it is aimed to evaluate demographic characteristics and injury properties of cases died during civil war in Syria.

METHODS: The postmortem examination and autopsy reports of 321 forensic deaths occurred between January and December 2012 were analyzed, retrospectively. Of the 321 forensic deaths, 186 cases were injured and died in the civil war in Syria and, therefore, included in the scope of the study. Four cases died by natural causes or traffic accidents were excluded.
\end{abstract}

RESULTS: Cases were most commonly $(n=73,39.2 \%)$ aged between 21 and 30 years, and $21.5 \%(n=40)$ of cases aged under 20 years. Of females, $68.8 \%(n=I I)$ were children and young adults under 20 years of age. An overwhelming majority of deaths ( $n=125,67.2 \%)$ were caused by explosive and shrapnel injuries, followed by $(n=49,26.3 \%)$ gunshot injuries related deaths.

CONCLUSION: This study indicated that a significant proportion of those who died after being injured in the Syrian war were children, women and elderly people. The nature and localization of the observed injuries indicated open attacks by military forces regardless of targets being civilians and human rights violations.

Key words: Autopsy; civilian deaths; Syrian war.

\section{INTRODUCTION}

People are widely exposed to adverse effects of wars worldwide. During wars, besides deaths of soldiers, high rates of civilian deaths have been reported. Injuries and deaths of soldiers and civilians were seen during the uprising in Syria in Arab Spring. Additionally, due to civil war, considerable social and medical problems were caused by migration to neighboring countries as refugees. ${ }^{[1,2]}$

Individuals injured in the civil war in Syria were mostly transferred to Hatay, a neighboring city of Turkey, for treatment. Among these, those who died were included in the scope of this study. Cases of deaths caused by injuries in the civil war

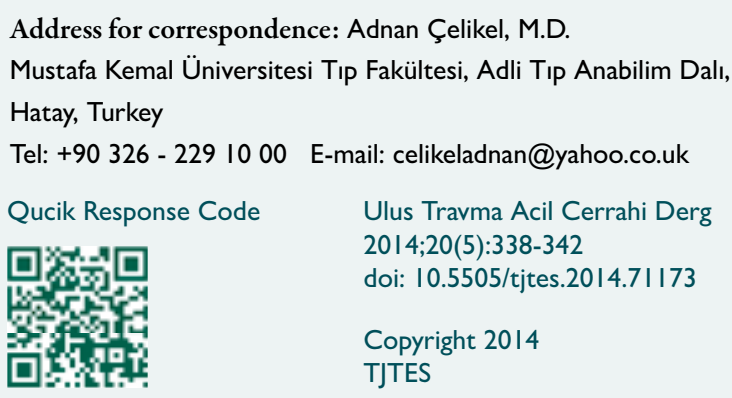

in Syria were evaluated in terms of demographic characteristics and features. Data collected was statistically analyzed and discussed in light of the related literature.

\section{MATERIALS AND METHODS}

The records of Hatay Public Prosecutor's Office were used. The postmortem examination and autopsy reports of 321 forensic deaths occurred between January and December 2012 were analyzed, retrospectively. Of the 32I forensic deaths, 186 deaths caused by injuries in the civil war in Syria were included in the scope of the study. Four cases that migrated to Turkey because of war and died by natural causes or traffic accidents were excluded from the study. Although sufficient information on the occupations of the cases could not be obtained, it was evaluated in accordance with the statements of their relatives. These cases were evaluated in terms of age, gender, injured body parts, and types of injury. Cases were assessed by two independent physicians using AIS (abbreviated injury scale) and ISS (Injury Severity Score). Data collected was statistically analyzed using SPSS (Statistical Package for Social Sciences) for Windows 13.0. Distribution between the ISS values and injury sites was evaluated by one way ANOVA test and a $p$ value of $<0.05$ was considered as statistically significant. 


\section{RESULTS}

Among the cases, 91.4\% $(n=170)$ were male and $8.6 \%(n=16)$ were female. Ages of males ranged between 2 and 89 years, while ages of females ranged between I and 60 years. Mean age of males and females were 32 and 18 years, respectively (Table I). Regarding age groups, a great number of cases $(n=73,39.2 \%)$ aged between 21 and 30 years. Among all, $21.5 \%(n=40)$ of cases aged under 20 years. Interestingly, $68.8 \%(n=11)$ of females were under 20 years of age. An overwhelming majority of deaths $(n=125,67.2 \%)$ were caused by explosive and shrapnel injuries, followed by $(n=49,26.3 \%)$ gunshot injuries related deaths. Among the remaining cases, twelve $(6.5 \%)$ were caused by blunt force traumas as a result of building collapse, fall from height and being thrown onto wreckage and etc. during explosions. Observed injuries were gunshot wounds, explosive and shrapnel injuries, burns and blunt traumatic injuries.

Eighteen out of 186 cases (9.7\%) were dead on admission to the hospital. Eighty-three out of 186 cases (44.6\%) died within the first 24 hours after arrival to the hospital. On the other hand, the rest $(n=85,45.7 \%)$ died during treatment within 2-120 days due to complications of primary injuries.

A great number of cases $(n=101,54.3 \%)$ suffered from multiple regional injuries, followed by head and neck $(n=45,24.2 \%)$ injuries (Table 2). In vast majority of cases, the cause of death

Table I. General properties of cases

\begin{tabular}{lccccc}
\hline & $\mathbf{n}$ & $\%$ & Minimum & Maximum & Mean \\
\hline Age (years) & & & & & \\
$\quad$ Men & 170 & 91.4 & 2 & 85.00 & $31.8 \pm 14.6$ \\
$\quad$ Women & 16 & 8.6 & 1 & 60.00 & $18.2 \pm 17.3$ \\
All cases & 186 & & 1 & 85 & $30.6 \pm 15.3$ \\
Injury Severity Score & 186 & & 16 & 75 & $43.0 \pm 21.5$ \\
Duration of treatment (days) & 186 & & 0 & 120 & $5.4 \pm 11.1$ \\
\hline
\end{tabular}

Table 2. Distribution of injured body parts

\begin{tabular}{lcc}
\hline Body part & $\mathbf{n}$ & $\%$ \\
\hline Head and Neck & 45 & 24.2 \\
Chest, Abdomen and Back & 28 & 15.3 \\
Extremities & 12 & 6.3 \\
Multiple parts & 101 & 54.3 \\
Total & 186 & 100 \\
\hline
\end{tabular}

Table 3. Distribution of causes of death

\begin{tabular}{lcc}
\hline Cause of death & $\mathbf{n}$ & $\%$ \\
\hline Brain hemorrhage and brain damage & 70 & 37.6 \\
Vascular damage and exsanguinations & 42 & 22.6 \\
Internal organ damage and internal hemorrhage & 30 & 16.2 \\
Internal organ damage and complications & 22 & 11.8 \\
Brain hemorrhage and internal hemorrhage & 15 & 8.1 \\
Bone fracture and complications & 4 & 2.2 \\
Spinal fractures and respiratory paralysis & 1 & 0.5 \\
Burns and complications & $\mathrm{I}$ & 0.5 \\
Brain damage and complications (meningitis) & $\mathrm{I}$ & 0.5 \\
Total & 186 & 100 \\
\hline
\end{tabular}


Table 4. Comparison of injury regions according to ISS

\begin{tabular}{llcccc}
\hline & Body regions & $\mathbf{n}$ & Mean & Std. Deviation & p* \\
\hline ISS & Head-Neck & 45 & 44.8889 & 25.01383 & 0.001 \\
& Multiple region & 101 & 47.2178 & 20.17355 & 0.001 \\
Chest-Abdomen & 28 & 31.0357 & 17.50023 & 0.001 \\
Extremity & 12 & 29.3333 & 11.22767 & 0.001
\end{tabular}

${ }^{*} \mathrm{p}<0.05$; ISS: Injury Severity Score.

was traumatic brain injury and hemorrhage, followed by exsanguinations due to damage of vessels and/or internal organs (Table 3) (Figure I).
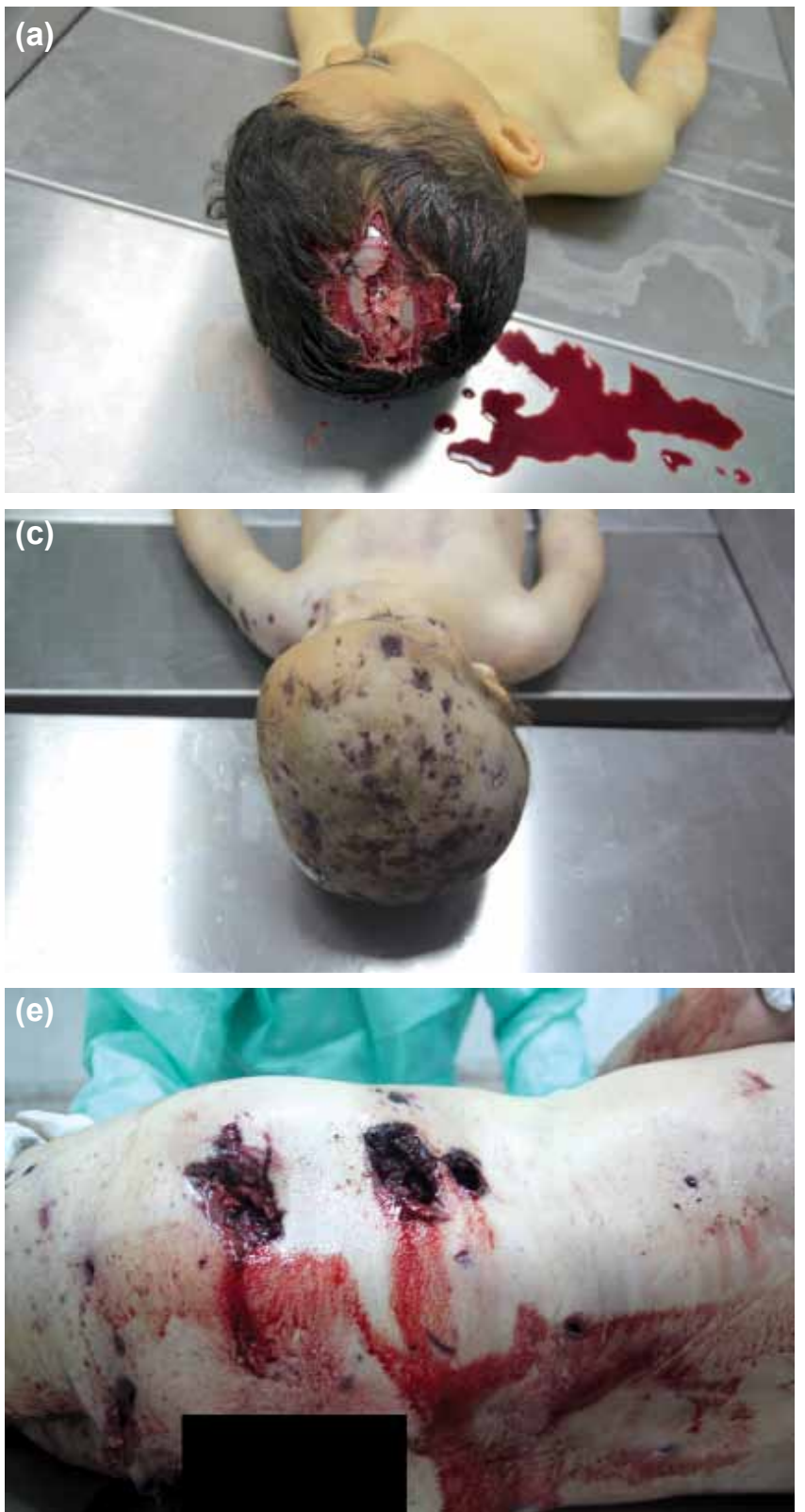

Figure 1. (a) Injury due to blunt trauma. (b) Injury due to explosion. (c-f) Shrapnel injury.
AIS scores were $\geq 4$ in all cases. AIS scores were 5 in $54.8 \%$ $(n=102)$, while 6 in $27.4 \%$ of cases. There was a statistically significant difference between ISS scores regarding injured
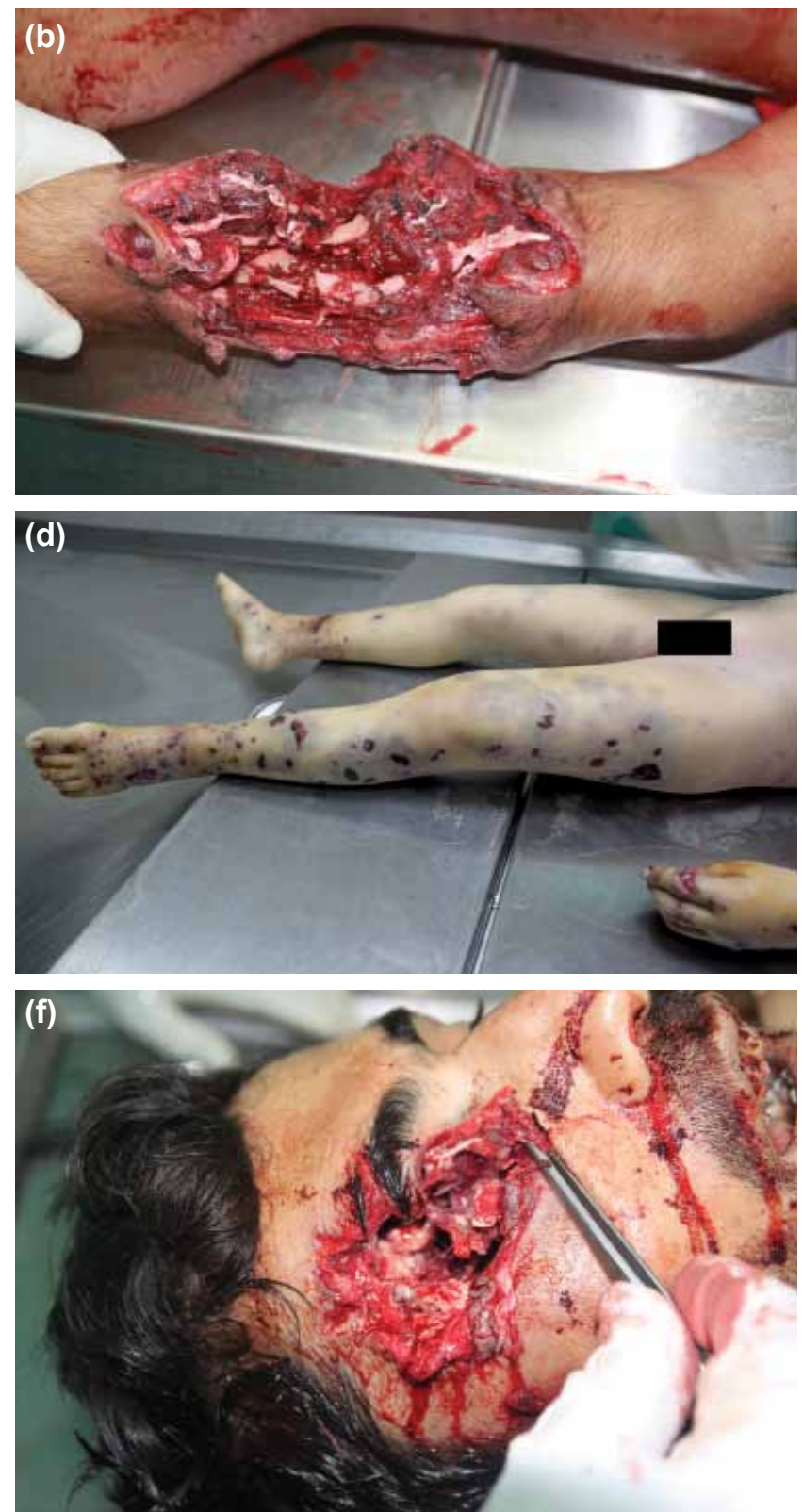
body parts, which was most significant in cases of head and neck injuries (Table 4) (Figure I).

\section{DISCUSSION}

$18.6 \%$ of deaths caused by firearm injuries all over the world have reportedly occurred during wars. War related injuries and deaths demonstrate different characteristics compared to civilian traumas. Civilian traumas are mostly blunt force traumas while war related traumas are mostly responsible for penetrated injuries caused by firearms and explosives (shrapnel, bullets, etc.). Injuries caused by pieces of shrapnel have been reported to be more fatal compared to injuries by bullets. ${ }^{[3-6]}$ Similar to the literature, in the presented series an overwhelming majority of deaths were $(n=125,67.2 \%)$ caused by shrapnel injuries due to explosions.

A study dealing with injured body parts during wars revealed that injury rates for different body parts were quite close. Head, neck, chest, and abdominal injuries were reported to be more fatal compared to injuries involving extremities. Most war related deaths have been reported to occur instantaneously at the incident scene or within the first 30 minutes after admission to a hospital. ${ }^{[7]}$ Another study interested in fatalities during the war in Croatia showed that injuries mostly involved muscle and soft tissue, followed by bony tissue, abdominal and thoracic regions. ${ }^{[6]}$ Studies concerning injuries caused by bombings presented that head and neck injuries were responsible for high morbidity and mortality. ${ }^{[8-13]}$ In our study, injuries involving multiple body parts took the first place, followed by injuries involving the head and neck region. AIS scores were $\geq 4$ in all cases. ISS scores were most significantly increased in cases of head and neck injuries. Similarly, in our series, the most common cause of death was head and neck injuries. High ratio of head and neck injuries, and injuries involving multiple body parts are thought to be the results of bombing attacks (air strikes, tank and mortar attacks, hand grenade explosions, and etc.).

Previously conducted studies showed that civilians were the ones mostly affected and human rights were violated during wars all over the world. During Croatian war, it was reported that out of $23 \%$ civilian deaths, $5.8 \%$ were children and $27.9 \%$ were females. ${ }^{[6]}$ Similarly, among injured individuals in Palestine, 9\% were women and $12 \%$ were children under 14 years of age. ${ }^{[5]}$ Dramatically, during the Gulf war, civilian injuries comprised $34 \% .{ }^{[14]}$ In accordance with the literature, among the fatalities presented in this study, women constituted $8.6 \%$, children and young adults under 20 years of age constituted $21.6 \%$, and individuals aged over 50 years constituted $10.8 \%$. The subjects in this study included patients injured during Syrian war and died in our city. In the presented series, injuries were induced by gunshot wounds, explosive and shrapnel injuries, and burns and blunt traumatic injuries. Interestingly, shrapnel injuries involved extensive tissue dam- age characterized with dirtiness and burned irregular edges. Bone fractures, brain and internal organ damages caused by small shrapnel pieces indicated high-energy impact. In addition, we believe that lack of a timely and professional first aid increased death risks.

Forensic autopsies were carried out to find out the mechanism, cause and manner of death, and to determine time of death, characteristics and severity of wounds, and factors contributing to death. Owing to its judicial nature, performing detailed forensic autopsies on bodies in the course of war is of high importance in terms of documenting the characteristics of injuries.

This study indicated that a significant proportion of those who injured and died in the Syrian war were children, women and elderly people. However, since cases exposed to more severe and fatal wounds died in the battlefield, the rate of civilian deaths is estimated to be much higher than presently reported. The nature and localization of the observed injuries suggested that these deaths might have been caused by air strikes indicating open attacks by military forces without discriminating civilians and opposition forces. Furthermore, obtained results are strongly indicative of significant human rights violations during the uprising and civil war in Syria.

Conflict of interest: None declared.

\section{REFERENCES}

1. Coupland RM, Meddings DR. Mortality associated with use of weapons in armed conflicts, wartime atrocities, and civilian mass shootings: literature review. BMJ 1999;319:407-10. CrossRef

2. Zeren C, Arslan MM, Aydoğan A, Özkalıpçı Ö, Karakuș A. Firearm injuries documented among Syrian refugees in Antakya Turkey. British Journal of Arts and Social Sciences 2012;5:1-5.

3. Rogov M. Pathological evaluation of trauma in fatal casualties of the Lebanon War, 1982. Isr J Med Sci 1984;20:369-71.

4. Bellamy RF. The medical effects of conventional weapons. World J Surg 1992;16:888-92. CrossRef

5. Helweg-Larsen K, Abdel-Jabbar Al-Qadi AH, Al-Jabriri J, BrønnumHansen H. Systematic medical data collection of intentional injuries during armed conflicts: a pilot study conducted in West Bank, Palestine. Scand J Public Health 2004;32:17-23. CrossRef

6. Hebrang A, Henigsberg N, Golem AZ, Vidjak V, Brnić Z, Hrabac P. Care of military and civilian casualties during the war in Croatia. [Article in Croatian] Acta Med Croatica 2006;60:301-7. [Abstract]

7. Scope A, Farkash U, Lynn M, Abargel A, Eldad A. Mortality epidemiology in low-intensity warfare: Israel Defense Forces' experience. Injury 2001;32:1-3. CrossRef

8. Peev MP, Naraghi L, Chang Y, Demoya M, Fagenholz P, Yeh D, et al. Real-time sample entropy predicts life-saving interventions after the Boston Marathon bombing. J Crit Care 2013;28:1109.e1-4.

9. Emile H, Hashmonai D. Victims of the Palestinian uprising (Intifada): a retrospective review of 220 cases. J Emerg Med 1998;16:389-94. CrossRef

10. Frykberg ER, Tepas JJ 3rd. Terrorist bombings. Lessons learned from Belfast to Beirut. Ann Surg 1988;208:569-76. CrossRef

11. Scott BA, Fletcher JR, Pulliam MW, Harris RD. The Beirut terrorist 
bombing. Neurosurgery 1986;18:107-10. CrossRef

12. Frykberg ER, Tepas JJ 3rd, Alexander RH. The 1983 Beirut Airport terrorist bombing. Injury patterns and implications for disaster management. Am Surg 1989;55:134-41.

13. Hadden WA, Rutherford WH, Merrett JD. The injuries of terrorist bombing: a study of 1532 consecutive patients. Br J Surg 1978;65:52531. CrossRef

14. Hinsley DE, Rosell PA, Rowlands TK, Clasper JC. Penetrating missile injuries during asymmetric warfare in the 2003 Gulf conflict. Br J Surg 2005;92:637-42. CrossRef

\section{KLINIK ÇALIŞMA - ÖZET}

\section{Suriye'deki savaş esnasında meydana gelen sivil ölümler}

Dr. Adnan Çelikel, ${ }^{1}$ Dr. Bekir Karaarslan, ${ }^{2}$ Dr. Dua Sümeyra Demirkıran, ${ }^{1}$ Dr. Cem Zeren, ${ }^{1}$ Dr. Muhammet Mustafa Arslan ${ }^{1}$

${ }^{1}$ Mustafa Kemal Üniversitesi Tıp Fakültesi, Adli Tıp Anabilim Dalı, Hatay;

${ }^{2}$ Gaziantep Üniversitesi Tıp Fakültesi, Adli Tıp Anabilim Dalı, Gaziantep

AMAÇ: Tüm dünyada ateşli silah yaralanmaları nedeniyle meydana gelen ölümlerin önemli bir kısmını savaş esnasında meydana gelmektedir. Bu çalışmada Suriye'deki iç savaş nedeniyle ölen olguların demografik özellikleri ve yaralanma niteliklerinin değerlendirilmesi amaçlandı.

GEREÇ VE YÖNTEM: Hatay merkezde 2012 Ocak-Aralık ayları arasında meydana gelen 32 I adli ölüm olgusunun ölü muayene ve otopsi tutanakları geriye dönük olarak incelendi. Suriye'de meydana gelen çatışmalar esnasında yaralanarak ölen I 86 olgu çalışma kapsamına alındı. Doğal hastalık veya trafik kazası sonucu ölen dört olgu çalışma dışı bırakıldı.

BULGULAR: Olgular en sık olguların 2I-30 yaş aralığında olduğu ( $n=73, \% 39.2$ ), 20 yaş altındaki olgu oranının \%2। 5 ( $n=40$ ) olduğu belirlendi. Kadın olguların \%68.8 ( $n=1$ I) oranında 20 yaş altı çocuk ve ergenler olduğu görüldü. Olguların \%67.2 ( $n=125)$ oranında bombalama ve şarapnel etkisi ile \%26.3'ünün ateşli silah mermi çekirdeği yaralanması sonucu öldüğü belirlendi.

TARTIŞMA: Sonuç olarak savaşta yaralanarak ölenlerin önemli bir bölümünün çocuk, kadın ve yaşlı kişiler olduğu görüldü. Yaralanma nitelik ve özellikleri silahsız sivillerin gözetilmeksizin yapılan saldırılar nedeniyle önemli insan hakları ihlalleri meydana gelmektedir.

Anahtar sözcükler: Otopsi; sivil ölümler; Suriye savaşı.

Ulus Travma Acil Cerrahi Derg 20।4;20(5):338-342 doi: 10.5505/tjtes.20।4.7।I73 